\title{
Influence of High Insertion Torque on Implant Placement - An Anisotropic Bone Stress Analysis
}

\author{
Bruno Salles SOTTO-MAIOR ${ }^{1}$ \\ Eduardo Passos ROCHA ${ }^{2}$ \\ Erika Oliveira de ALMEIDA² \\ Amilcar Chagas FREITAS-JÚNIOR² \\ Rodolfo Bruniera ANCHIETA ${ }^{2}$ \\ Altair Antoninha DEL BEL CURY ${ }^{1}$
}

\begin{abstract}
${ }^{1}$ Department of Prosthodontics and Periodontology, Piracicaba Dental School, University of Campinas, Piracicaba, SP, Brazil

${ }^{2}$ Department of Dental Materials and Prosthodontics, Araçatuba Dental School, São Paulo State University, Araçatuba, SP, Brazil
\end{abstract}

\begin{abstract}
The aim of this study was to evaluate the influence of the high values of insertion torques on the stress and strain distribution in cortical and cancellous bones. Based on tomography imaging, a representative mathematical model of a partial maxilla was built using Mimics 11.11 and Solid Works 2010 softwares. Six models were built and each of them received an implant with one of the following insertion torques: $30,40,50,60,70$ or $80 \mathrm{Ncm}$ on the external hexagon. The cortical and cancellous bones were considered anisotropic. The bone/implant interface was considered perfectly bonded. The numerical analysis was carried out using Ansys Workbench 10.0. The convergence of analysis $(6 \%)$ drove the mesh refinement. Maximum principal stress $\left(\sigma_{\max }\right)$ and maximum principal strain $\left(\varepsilon_{\max }\right)$ were obtained for cortical and cancellous bones around to implant. Pearson's correlation test was used to determine the correlation between insertion torque and stress concentration in the periimplant bone tissue, considering the significance level at 5\%. The increase in the insertion torque generated an increase in the $\sigma_{\max }$ and $\varepsilon_{\max }$ values for cortical and cancellous bone. The $\sigma_{\max }$ was smaller for the cancellous bone, with greater stress variation among the insertion torques. The $\varepsilon_{\max }$ was higher in the cancellous bone in comparison to the cortical bone. According to the methodology used and the limits of this study, it can be concluded that higher insertion torques increased tensile and compressive stress concentrations in the periimplant bone tissue.
\end{abstract}

Key Words: dental implants, insertion torque, finite element method.

\section{INTRODUCTION}

Over the last 30 years, clinical studies with osseointegrated implants have shown excellent longterm results, with over $90 \%$ success rate $(1,2)$. However, early failures may occur during the healing process affecting osseointegration (3). These failures may have biological causes, such as periimplantitis and systemic diseases. In addition, biochemical factors can negatively influence implant success; for instance, bone over heating during the surgical procedure, occlusal overload, besides the effects of tensile strength, shear and compressive stresses in the peri-implant bone tissue (4).

The osseointegration process requires ideal stress levels to maintain normal bone repair (5). Excessive tension may cause irreversible damage to the periimplant bone tissue (6). Conversely, too low tension may unsatisfactorily stimulate the bone repair process (4). Recent computerized simulations have suggested that compressive stresses and hydrostatic tensions of the interstitial liquid may modulate tissue differentiation and bone remodeling $(4,7,8)$. Byrne et al. (7), using mathematical models about cellular differentiation in bone repair, verified that the stress increase changes the bone repair process, reducing the amount of newly formed bone tissue by $23 \%$ and increasing the amount of cartilage by $21 \%$. Similarly, Checa and Prendergast (8) verified less newly formed bone and greater connective

Correspondence: Profa. Dra. Altair Antoninha Del Bel Cury, Departamento de Prótese e Periodontia, Faculdade de Odontologia de Piracicaba, Universidade de Campinas, CP 52, 13414-903 Piracicaba, SP, Brasil. Tel: +55-19-2106-5294. Fax: +55-19-2106-5211. e-mail: altcury@fop.unicamp.br 
tissue formation under elevated compressive stresses.

During placement of osseointegrated implants, the insertion torque may result in varied levels of compressive stresses transmitted to the adjacent bone, given that the implant bed is slightly narrower than the diameter of the implant to be placed in order to optimize primary stabilization $(9,10)$. Clinical studies have demonstrated a close relationship between initial stabilization and the success of an osseointegrated implant (11-13), which can be measured by the insertion torque during implant placement (12). The insertion torque must exceed $30 \mathrm{Ncm}$ to obtain predictable success rates $(12,14)$, aiming at avoiding implant micromovement and consequent connective tissue formation $(6,13)$. However, an excessively high insertion torque, above $50 \mathrm{Ncm}$ (15), can occur during dense bone implant placement $(12,16,17)$, resulting in the transmission of high compressive stresses to the adjacent bone, in addition to compromising osseointegration success (3).

This way, the understanding of the high values of insertion torque that can be used during implant placement, without causing excessive stress in the bone tissue, would be helpful for the success of implant osseointegration.

Considering the lack of studies associating compressive stress and strain with the high values of the insertion torques during implant placement, the aim of the present study was to evaluate the influence of different insertion torques on stress and strain distribution in cortical and cancellous bones, using the three-dimensional finite element method.

\section{MATERIAL AND METHODS}

After approval by the local Research Ethics Committee and signature of an informed consent form, a computed tomography (CT) scan was taken from a patient to obtain dicom format images. A representative mathematical model of the anterior segment of the maxilla was built using Mimics 11.11 software (Interactive Medical Image Control System, Materialise Inc., Leuven, Belgium) and Solid Works 2010 software (Dassault Systèmes SolidWorks Corporation, Concord, MA, USA).

The geometry of an external hexagonal implant of 4.5 x $11.5 \mathrm{~mm}$ (Strong SW model; Sistema de ImplantesSIN, São Paulo, SP, Brazil) was used to build the implant design (Fig. 1A) with the aided of the Solid Works 2010 software. This implant was adapted to the bone segment corresponding to the region of the maxillary right central incisor (Fig. 1B).

After building, the initial model was imported to the finite element program Ansys Workbench 10.0 (Swanson Analysis Systems Inc., Houston, PA, USA) to determine the regions and generate the finite element
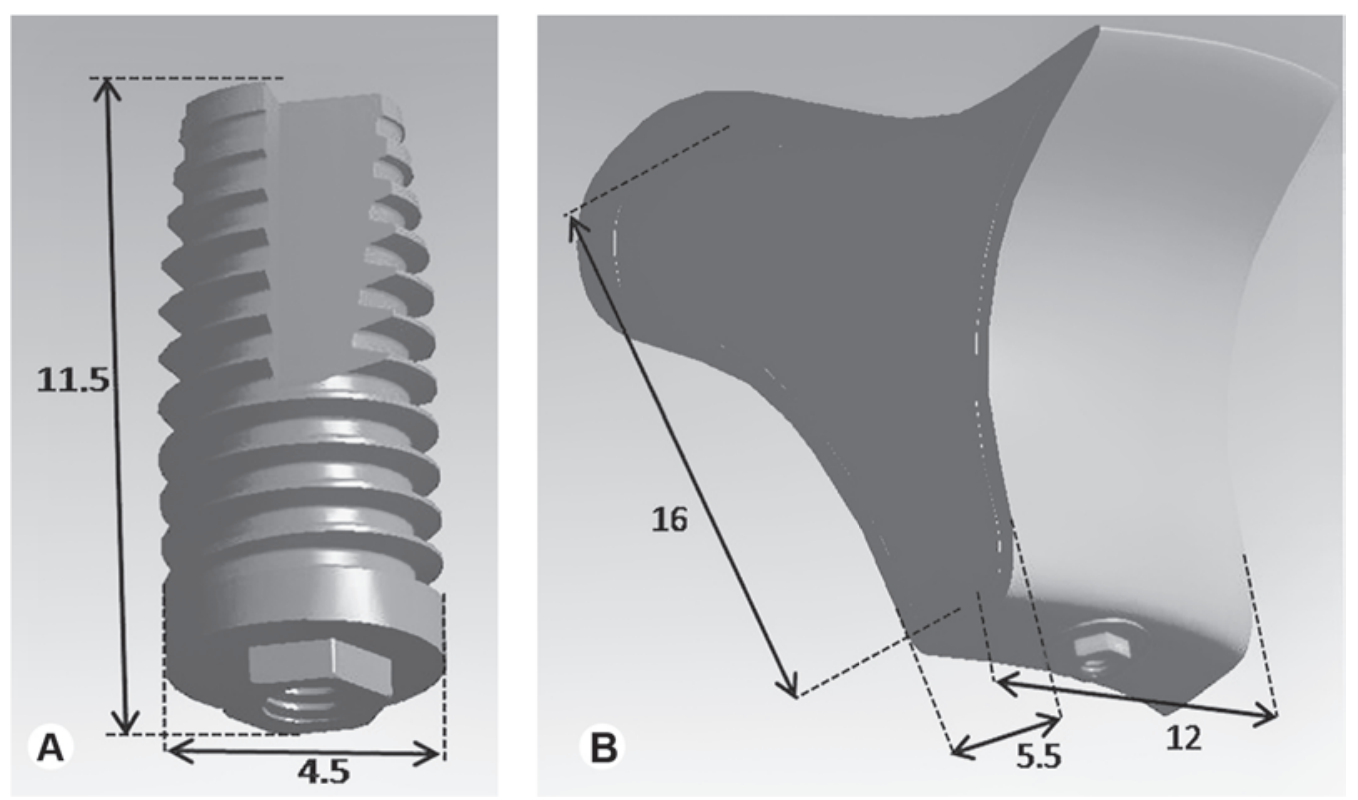

Figure 1. Implant dimensions (A) and model dimensions with cortical and cancellous bones (B) expressed in millimeters. 
mesh. Each model received an implant with one of the following insertion torques: $30,40,50,60,70$ or $80 \mathrm{Ncm}$ on the external hexagon. These values were applied using six forces on the implant external hexagon, perpendicular to the long axis and tangent to the implant platform, determined by the following equation (Fig. 2):

\section{$\mathrm{F}=\mathrm{T} / 6 \times \mathrm{D} \times \operatorname{sen} \theta$}

Where $\mathrm{T}$ is the insertion torque; $\mathrm{D}$ is a point of force application to the rotating axis; and $\theta$ is the angle formed by the direction of the force applied and the plan of force application.

The mechanical properties for the anisotropic behavior of the cancellous and cortical bones were based on specific literature (18) (Table 1). The implant material was considered homogeneous (titanium) and isotropic with values of Young's modulus $=104,000$ $(\mathrm{MPa})$; shear modulus $=38,806(\mathrm{MPa})$; Poisson's ratio $=0.340(\mathrm{MPa})(18)$. The bone/implant interface was considered perfectly bonded.

Parabolic tetrahedral elements of $0.8 \mathrm{~mm}$ were used for the mesh. The mesh refinement was established by the convergence of analysis $(6 \%)$. The models presented 170,504 nodes and 112,507 elements. The implant presented 92,432 nodes and 62,483 elements. The cancellous and cortical bones presented 58,463 and 19,609 nodes and 39,442 and 10,582 elements, respectively. A zero-displacement boundary condition was applied to the three Cartesian axes $(\mathrm{x}=\mathrm{y}=\mathrm{z}=0)$.

Maximum principal stress $\left(\sigma_{\max }\right)$ and maximum principal strain $\left(\varepsilon_{\max }\right)$ were obtained for the cortical and cancellous bones around the implant. Pearson's correlation test was used to determine the relationship between the insertion torques and stress concentrations, considering the significance level at 5\%.

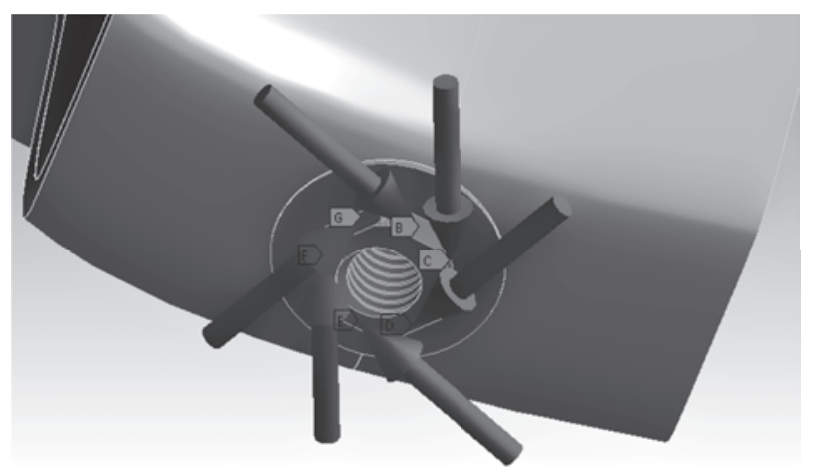

Figure 2. Torque applied to implant on implant external hexagon.

\section{RESULTS}

In general, there was higher stress in the cancellous and cortical bones after increasing the insertion torques. The $\sigma_{\max }$ was smaller for the cancellous bone, with greater stress variation among the insertion torques. The $\varepsilon_{\max }$ was higher in the cancellous bone than in the cortical bone.

\section{Cancellous Bone}

Stress distribution in cancellous bone is presented in figure 3. The $\sigma_{\max }$ for different insertion torques of 30,40 and $50 \mathrm{~cm}$ were $0.114,0.144$ and $0.168 \mathrm{MPa}$, respectively. There was an increase in the main stresses between insertion torques of 50 and $60 \mathrm{Ncm}$, varying from 0.168 to $1.09 \mathrm{MPa}$, maintaining a linear increase with 70 and $80 \mathrm{Ncm}$, exhibiting 1.17 and $1.34 \mathrm{MPa}$, respectively. The insertion torques showed a significant correlation with $\sigma_{\max }$ and $\varepsilon_{\max }(\mathrm{r}=1.0, \mathrm{p}=0.001)$.

The 30 and $80 \mathrm{Ncm}$ insertion torques showed the lowest $\left(7.20 \times 10^{-4} \mathrm{MPa}\right)$ and and highest $\left(\varepsilon_{\max } 19.2 \times\right.$ $10^{-4} \mathrm{MPa}$ ) main stresses, respectively.

\section{Cortical Bone}

The stresses distribution in cortical bone is

Table 1. Material properties used in anisotropic model. Material axes correspond to global coordinate system shown in figure 1 . $\mathrm{E}=$ Young's modulus. $\mathrm{G}=$ shear modulus. $v_{\mathrm{ij}}=$ Poisson's ratio for strain in $\mathrm{j}$-direction when loaded in i-direction.

\begin{tabular}{lcc}
\hline & Cancellous bone & Cortical bone \\
\hline $\mathrm{E}_{\mathrm{X}}(\mathrm{MPa})$ & 1,148 & 12,600 \\
$\mathrm{E}_{\mathrm{Y}}(\mathrm{MPa})$ & 210 & 12,600 \\
$\mathrm{E}_{\mathrm{Z}}(\mathrm{MPa})$ & 1,148 & 19,400 \\
$\mathrm{G}_{\mathrm{XY}}(\mathrm{MPa})$ & 68 & 4,850 \\
$\mathrm{G}_{\mathrm{YZ}}(\mathrm{MPa})$ & 68 & 5,700 \\
$\mathrm{G}_{\mathrm{XZ}}(\mathrm{MPa})$ & 434 & 5,700 \\
$v_{\mathrm{YX}}$ & 0.010 & 0.300 \\
$v_{\mathrm{ZY}}$ & 0.055 & 0.390 \\
$v_{Z X}$ & 0.322 & 0.390 \\
$v_{X Y}$ & 0.055 & 0.300 \\
${ }_{v} \mathrm{YZ}$ & 0.010 & 0.253 \\
$v_{X} \mathrm{C}$ & 0.322 & 0.253 \\
\hline
\end{tabular}


presented in Figure 4. The insertion torques showed significant correlation with $\sigma_{\max }$ and $\varepsilon_{\max }(\mathrm{r}=1.0$, $\mathrm{p}=0.001$ ). The models with insertion torques of $30 \mathrm{Ncm}$ and $80 \mathrm{Ncm}$ showed the lowest $\sigma_{\max }(4.15 \mathrm{MPa})$ and $\varepsilon_{\max }$ $\left(3.64 \times 10^{-4}\right)$, and the highest $\sigma_{\max }(11.1 \mathrm{MPa})$ and $\varepsilon_{\max }$ $\left(9.72 \times 10^{-4}\right)$ values, respectively.

\section{DISCUSSION}

An adequate stability of the dental implant in
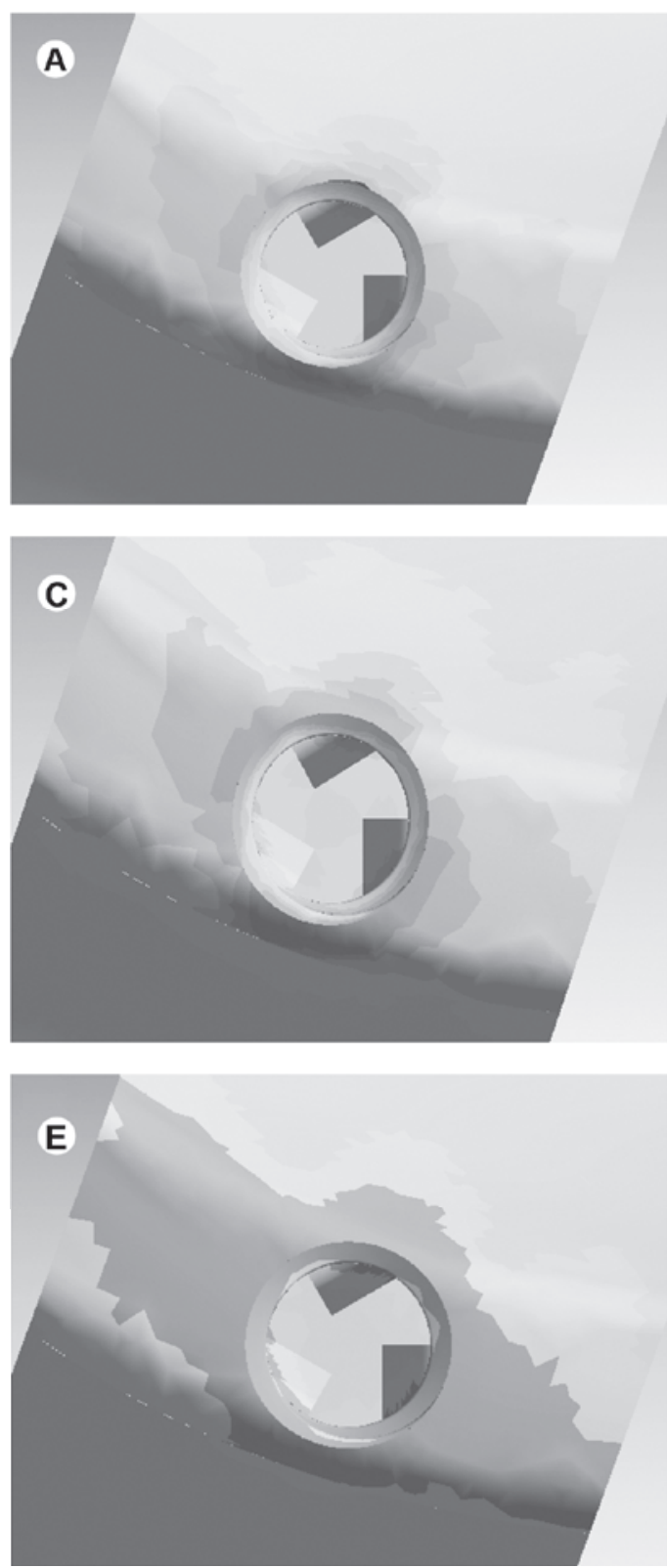

the surrounding bone plays an important role in the bone healing processes, avoiding micromovement and damage to the bone healing process $(17,19)$. Clinical assessment of primary stability can be performed by the implant insertion torque at the moment of placement (19). Considering the importance of the insertion torque for the osseointegration process, this study was performed by mimicking a dental implant placement using the anisotropic finite element technique. It was hypothesized that high values of the insertion torque can generate
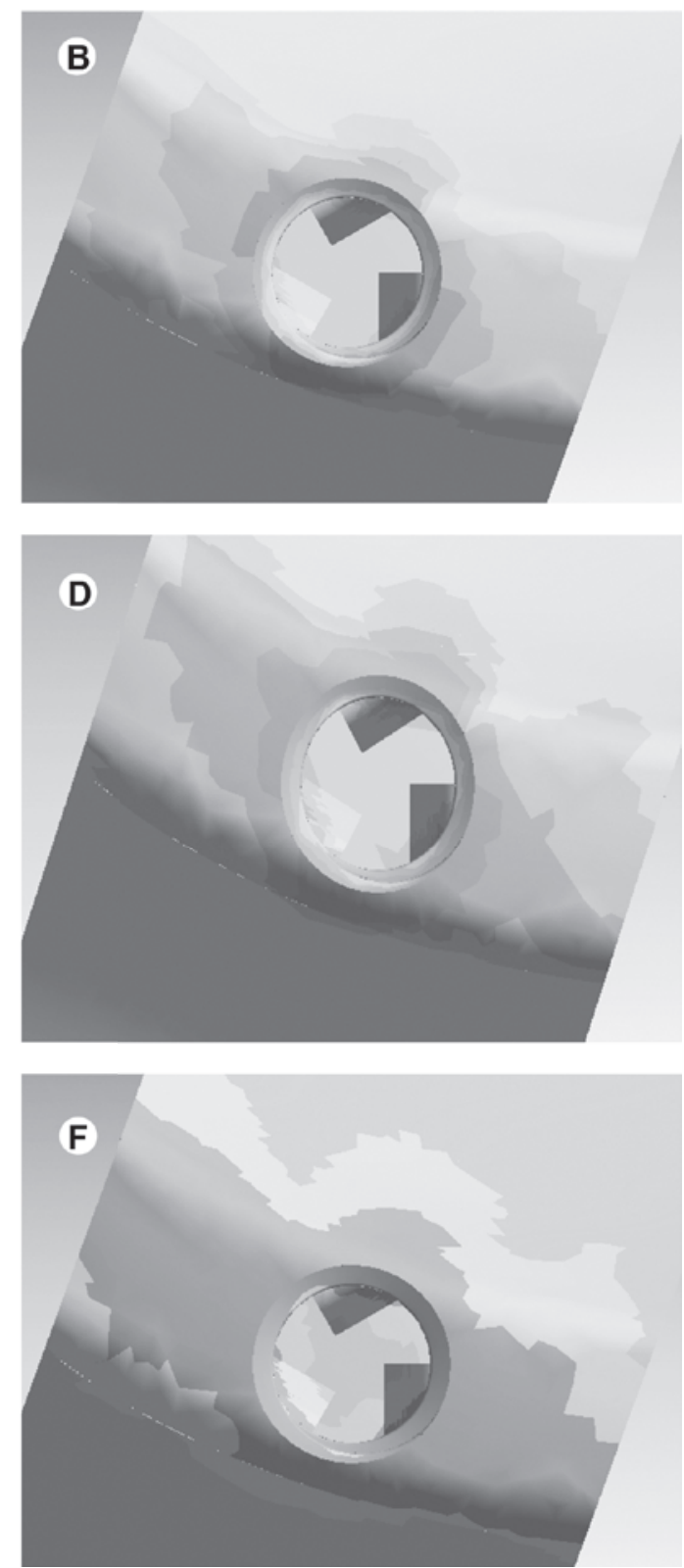

Figure 3. Stress profile within cancellous bone at each torque insertion. $A=30 \mathrm{Ncm} ; \mathrm{B}=40 \mathrm{Ncm} ; \mathrm{C}=50 \mathrm{Ncm} ; \mathrm{D}=60 \mathrm{Ncm} ; \mathrm{E}=70$ $\mathrm{Ncm} ; \mathrm{F}=80 \mathrm{Ncm}$. 
overcompressive stress to the peri-implant tissues and compromising osseointegration process.

According to Ottoni et al. (14) and Irinakis and Wiebe (12), the insertion torque must exceed $30 \mathrm{Ncm}$, especially for immediate load implants. However, insertion torques above $50 \mathrm{Ncm}$ are considered high (15) and generally induce excessive compressive stresses to the bone periimplant. Some studies have reported that the increase of compressive stress in the bone tissue may lead to failure in the bone healing (5) and osseointegration process (3).

The present study showed similar results to those of a previous study (4), in which the increase of the insertion torque generates higher compressive stress concentrations to the peri-implant bone tissue. In the present study, for the cancellous bone tissue, the increase of insertion torque (from 30 to $80 \mathrm{Ncm}$ ) showed an increase of $1175 \%$ for the maximum principal stress and $266 \%$ for the maximum principal strain. In the cortical bone tissue both stresses were higher (267\%).
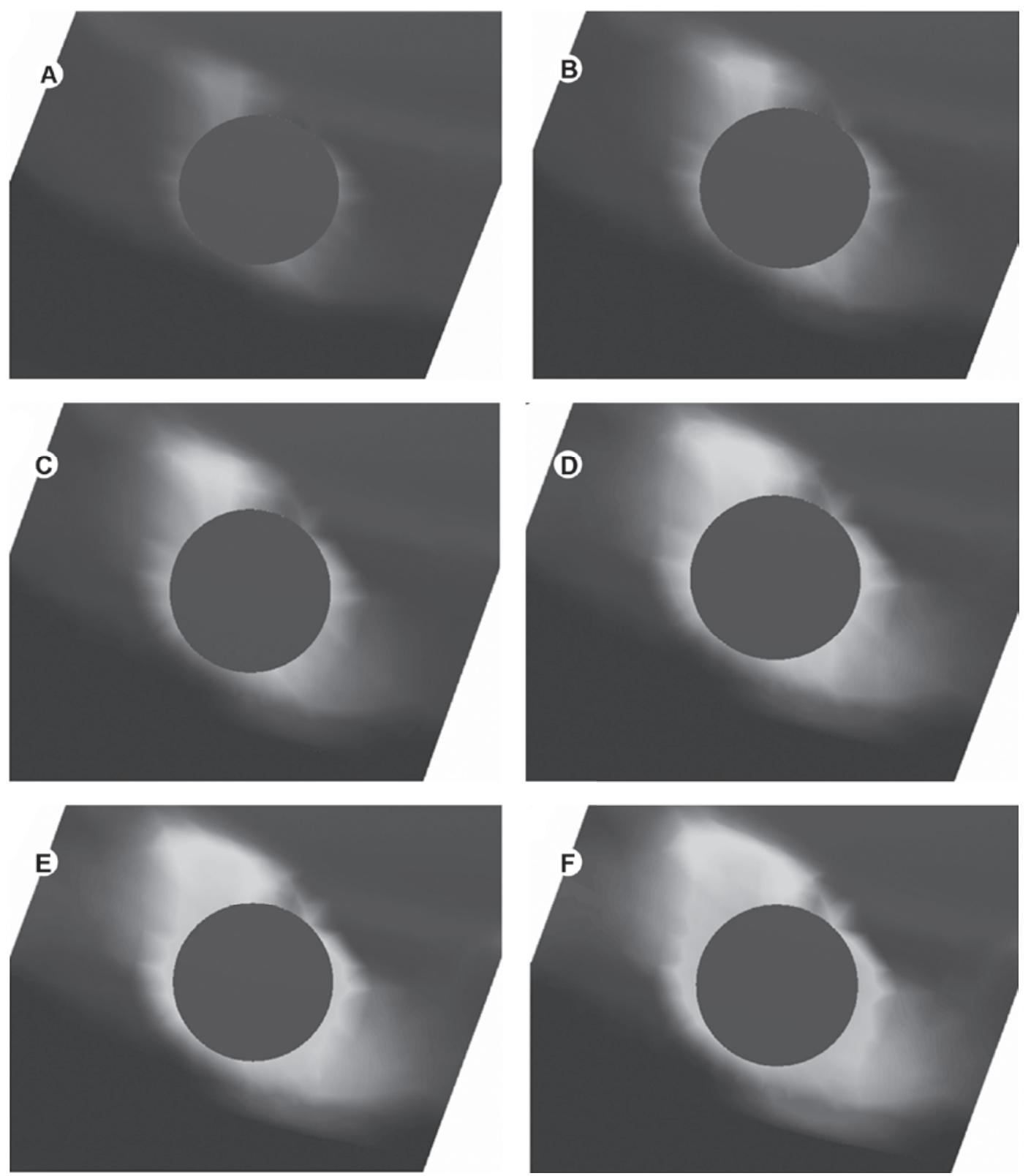

Figure 4. Stress profile within cortical bone at each torque insertion. $A=30 \mathrm{Ncm} ; \mathrm{B}=40 \mathrm{Ncm} ; \mathrm{C}=50 \mathrm{Ncm} ; \mathrm{D}=60 \mathrm{Ncm} ; \mathrm{E}=70 \mathrm{Ncm}$; $\mathrm{F}=80 \mathrm{Ncm}$. 
Studies based on mathematical analyses of the bone healing process presented a correlation between the compressive stress and the type of tissue formed during bone remodeling in vivo (8). It is important to draw attention to the fact that under high stresses, significant alterations occurred in the angiogenesis dynamics impairing the formation of new blood vessels, causing hypoxia in the periimplant tissues, thus inhibiting bone formation and favoring the formation of cartilage and connective tissue (8). It has also been emphasized the model of bone tissue formed by a complex threedimensional tubule network filled with an interstitial fluid that supplies bone cells (20). This fluid would be able to transmit external stresses to bone cells through a mechanism known as mechanotransduction, which refers to the conversion of mechanical energy from external stresses into bioelectrical and biochemical signals that modulate the bone cell metabolism (20). Therefore, when this mechanical energy is too high, osteocytes are induced to death, followed by recruitment of osteoclasts and bone destruction $(8,20)$.

The results of the present study demonstrated that the maximum principal stress increased by $648 \%$, from 0.168 to $1.09 \mathrm{MPa}$, between torques of 50 and $60 \mathrm{Ncm}$ in the cancellous bone. High insertion torques above 50 $\mathrm{Ncm}$ (15) can generate high compressive stresses to the peri-implant tissues causing blood supply deficiency and bone necrosis during the osseointegration phase and early implant failure (3) usually within the first month after placement (3). A high insertion torque may occur during implant placement in high density bone tissue $(12,16,17)$. This observation has been demonstrated in a study that evaluated the relationship between bone density and the maximum insertion torque supported by the bone tissue, using computer tomography images and Hounsfield scale, and found a significant correlation between bone density, insertion torque and primary stability (17).

The cortical bone tissue had lower capacity to dissipate stress as well as a more uniform increase of the insertion torque, showing higher principal maximum stress in comparison with the cancellous tissue. These results are similar to those of previous studies $(9,10)$, which assessed the influence of the osteotomy diameter for implant placement and the stress concentration on implant threads. These results are explained by the different mechanical properties between cancellous and cortical bones.

The computational analysis by finite elements shows great versatility in the analysis of complex models. This analytical method allowed identifying the homogeneity between different models with varied insertion torques that are difficult to obtain in an experimental study with physical models, as well as the same mechanical properties and dimensions for cancellous and cortical bones. The anisotropy found in the bone tissue was reproduced in the present study for the cortical and cancellous bones, being characterized by different stress responses under forces applied in varied directions (9). Although the results of the present study can add data to the implant/bone behavior influenced by the high values of the insertion torque, further animal and clinical investigation studies are needed to confirm these findings.

According to the methodology used and within the limitations of the present study, it may be concluded that high insertion torques can generate higher tensile and compressive stresses to the periimplant bone tissue.

\section{RESUMO}

O objetivo deste estudo foi avaliar a influência dos altos valores de torque de inserção na distribuição de tensões e deformações no osso cortical e medular. Com base em imagens de tomografia computadorizada, um modelo matemático representativo de um segmento da maxila foi construído utilizando os programas Mimics 11.11 e Solid Works 2010. Seis modelos foram construídos e cada um recebeu um implante com os seguintes torques de inserção no hexágono externo: 30, 40, 50, 60, $70 \mathrm{ou} 80 \mathrm{Ncm}$. O osso cortical e medular foi considerado anisotrópico. A interface osso/ implante foi considerada perfeitamente unida. A análise numérica foi realizada através do Ansys Workbench 10.0. A convergência de análise $(6 \%)$ determinou o refinamento da malha. A tensão máxima principal $\left(\sigma_{\max }\right)$ e a deformação máxima principal $\left(\varepsilon_{\max }\right)$ foram obtidos para o osso cortical e medular ao redor do implante. O teste de correlação de Pearson foi utilizado para determinar a correlação entre torque de inserção e de concentração de tensões e deformações no tecido ósseo peri-implantar, considerando o nível de significância de 5\%. O aumento no torque de inserção gerou um aumento nos valores $\sigma_{\max }$ e $\varepsilon_{\max }$ para o osso cortical e medular. $\mathrm{O} \sigma_{\max }$ foi menor para o osso medular, com maior variação de tensão entre os torques de inserção. $O \varepsilon_{\max }$ foi maior no osso medular em relação ao osso cortical. De acordo com a metodologia utilizada e com os limites do estudo, pode-se concluir que torques alto de inserção aumentou as concentrações de tensões de tração e compressão no tecido ósseo peri-implantar.

\section{ACKNOWLEDGEMENTS}

This research was supported by the São Paulo State Research Foundation - FAPESP (Grant \#2009/14982-4).

\section{REFERENCES}

1. Hussaini S, Weiner S, Ahmad M. Implant survival rates in a 
condensed surgical and prosthetic training program for general practitioners in dental implants. Implant Dent 2010;1:73-80.

2. Mangano C, Mangano F, Piattelli A, Iezzi G, Mangano A, La Colla L. Prospective clinical evaluation of 1920 Morse taper connection implants: results after 4 years of functional loading. Clin Oral Implants Res 2009;3:254-261.

3. Ricomini Filho AP, Fernandes FSF, Straioto FG, Silva WJ, Del Bel Cury AA. Preload loss and bacterial penetration on different implant-abutment connection systems. Braz Dent J 2010;21:123129.

4. Van Staden RC, Guan H, Johnson NW, Loo YC, Meredith N. Step-wise analysis of the dental implant insertion process using the finite element technique. Clin Oral Implants Res 2008;3:303-313.

5. Degidi M, Perrotti V, Strocchi R, Piattelli A, Iezzi G. Is insertion torque correlated to bone-implant contact percentage in the early healing period? A histological and histomorphometrical evaluation of 17 human-retrieved dental implants. Clin Oral Implants Res 2009;8:778-781.

6. Warreth A, Polyzois I, Lee CT, Claffey N. Generation of microdamage around endosseous implants. Clin Oral Implants Res 2009;12:1300-1306.

7. Byrne DP, Lacroix D, Planell JA, Kelly DJ, Prendergast PJ. Simulation of tissue differentiation in a scaffold as a function of porosity, Young's modulus and dissolution rate: application of mechanobiological models in tissue engineering. Biomaterials 2007;36:5544-5554.

8. Checa S, Prendergast PJ. Effect of cell seeding and mechanical loading on vascularization and tissue formation inside a scaffold: a mechano-biological model using a lattice approach to simulate cell activity. J Biomech 2010;5:961-968.

9. Natali AN, Carniel EL, Pavan PG. Investigation of viscoelastoplastic response of bone tissue in oral implants press fit process. J Biomed Mater Res B Appl Biomater 2009;2:868-875.

10. Natali AN, Carniel EL, Pavan PG. Dental implants press fit phenomena: biomechanical analysis considering bone inelastic response. Dent Mater 2009;5:573-581.
11. Akca K, Chang TL, Tekdemir I, Fanuscu MI. Biomechanical aspects of initial intraosseous stability and implant design: a quantitative micro-morphometric analysis. Clin Oral Implants Res 2006;4:465-472.

12. Irinakis $\mathrm{T}$, Wiebe $\mathrm{C}$. Initial torque stability of a new bone condensing dental implant. A cohort study of 140 consecutively placed implants. J Oral Implantol 2009;6:277-282.

13. Rodrigo D, Aracil L, Martin C, Sanz M. Diagnosis of implant stability and its impact on implant survival: a prospective case series study. Clin Oral Implants Res 2010;21:255-261.

14. Ottoni JM, Oliveira ZF, Mansini R, Cabral AM. Correlation between placement torque and survival of single-tooth implants. Int J Oral Maxillofac Implants 2005;5:769-776.

15. Duyck J, Corpas L, Vermeiren S, Ogawa T, Quirynen M, Vandamme K, et al.. Histological, histomorphometrical, and radiological evaluation of an experimental implant design with a high insertion torque. Clin Oral Implants Res 2010;21:877-884.

16. Tabassum A, Meijer GJ, Wolke JG, Jansen JA. Influence of surgical technique and surface roughness on the primary stability of an implant in artificial bone with different cortical thickness: a laboratory study. Clin Oral Implants Res 2010;2:213-220.

17. Turkyilmaz I, Sennerby L, McGlumphy EA, Tozum TF. Biomechanical aspects of primary implant stability: a human cadaver study. Clin Implant Dent Relat Res 2009;2:113-119.

18. O'Mahony AM, Williams JL, Spencer P. Anisotropic elasticity of cortical and cancellous bone in the posterior mandible increases peri-implant stress and strain under oblique loading. Clin Oral Implants Res 2001;6:648-657.

19. Nedir R, Bischof M, Szmukler-Moncler S, Bernard JP, Samson J. Predicting osseointegration by means of implant primary stability. Clin Oral Implants Res 2004;5:520-528.

20. Burger EH, Klein-Nulend J. Mechanotransduction in bone--role of the lacuno-canalicular network. FASEB J 1999:S101-S112.

Accepted November 4, 2010 